CENTRO, Vol. 1, No. 2, 1985, pp. 1-19.

c) University of Malta Press.

\title{
The geology of the Pelagian Islands and their structural setting related to the Pantelleria rift (central Mediterranean Sea)
}

\author{
MARIO GRASSO* H. MARTYN PEDLEY,** and CLAUS-DIETER REUTHER*** \\ * Istituto Scienza della Terra, \\ Universitá di Catania, Corso Italia 55, 95129 Catania, Italy. \\ ** Department of Geology, Hull University, \\ Hull, North Humberside, HU6 7RX, Great Britain. \\ *** Geologisches Institut, Universität Karlsruhe, \\ Kaiserstrasse 12, 7500, Karlsruhe, Fed. Rep. of Germany.
}

(Received 6th May 1985)

\begin{abstract}
The Pelagian islands of Lampedusa, Lampione and Linosa form a natural laboratory in which, through the analysis of synsedimentary patterns and fault kinematics, to model the history of compressional and tensional structures from Upper Miocene to recent times.

This information correlates remarkably well and compliments recent detailed studies on the Maltese Islands lying on the opposite shoulder of the Pantelleria Rift.

The upper Miocene onset of rifting is deduced from synsedimentary faulting on Lampedusa. The continuation of the same tectonic regime up to the present time can be recognized on the Quaternary volcanic island of Linosa where volcanic activity is related to structures paralleling the Lampedusa trend.

In the central Mediterranean area, NW-SE trending structures are characterized by normal faulting and are present from the Ionian side of the Hyblean Plateau (SE Sicily) through Malta and into central Tunisia. A second NNW-SSE trending fault pattern reveals evidence of sinistral motion as can be demonstrated in Lampedusa. This activity commenced in Upper Miocene and continues to recent time. The movements associated with the two fault trends are consistent with a northwestward directed maximal horizontal compressive stress.
\end{abstract}




\section{Introduction}

Although the northern margin of the Maghreb is broken only by the Sicily Channel and the narrow Strait of Messina, the foreland of the African plate in this area is largely submerged. On the Pelagian shelf apart from Tunisia and the Hyblean Plateau (S.E Sicily), there are only a few small islands, Malta, Gozo, the Pelagian Islands, and relatively little oceanographic data. Yet the area is of considerable importance because of the extensive tectonic and volcanic activity affecting the region.

In the first part of this paper the study of the geology of Lampedusa leads to a palaeogeographic pattern for sedimentation in Upper Miocene which, for the first time, can be closely related to tectonic activity. Small though these islands are, the information they provide is an important key to the neotectonic evolution of the Pelagian Block. That information clears the way to the understanding of the neotectonic history of the Pelagian Block when considered in conjunction with the sedimentological and tectonic observations from the better known areas of Malta, SE Sicily and Tunisia. This forms the theme of the second part of this paper.

The Pelagian Islands (Fig. 1) lie almost midway between the eastern Tunisian coast and southern Sicily (Central Mediterranean Sea). Of the three islands, Linosa, the most northerly, is entirely volcanic whereas Lampedusa is composed of a Late Miocene

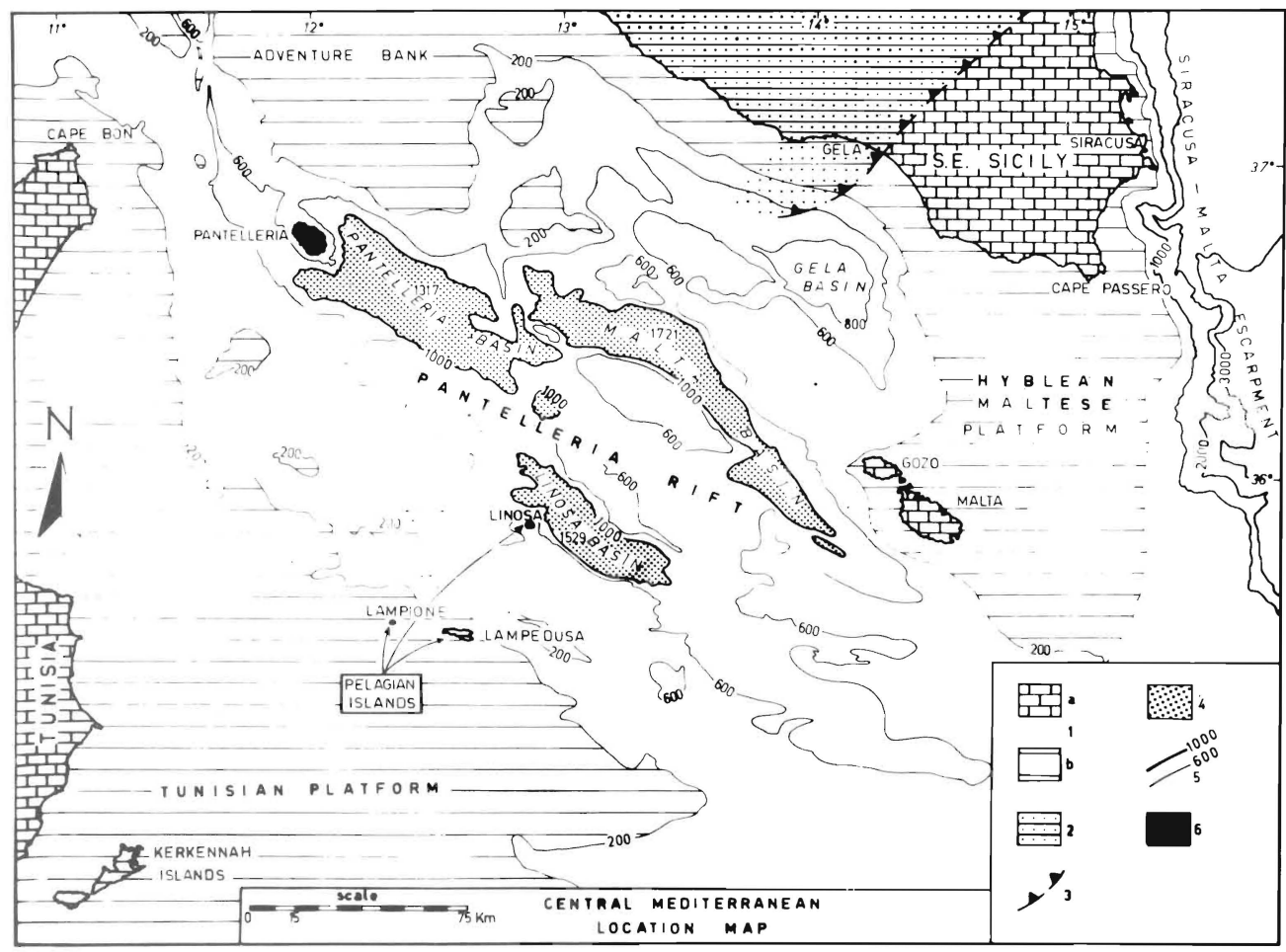

Fig. 1. Location map of the Pelagian Islands and surrounding central Mediterranean region: 1) Pelagian shelf: a) Tertiary platform carbonates of SE Sicily, the Maltese Islands and East Tunisia, b) submerged Hyblean-Maltese platform and Tunisian platform; 2) Central Sicily (southernmost area of Pliocene thrusts); 3) Plio-Quaternary collision front, 4) Deep basins (individual segments of the Pantelleria Rift) within the Pelagian Block; 5) present day bathymetric contours in metres (after Morelli et al., 1975); 6) Emergent volcanic islands. 
carbonate platform sequence and the islet of Lampione, west of Lampedusa, is composed of Eocene platform carbonates. The two carbonate dominated islands have recently been studied by Bonnefous and Bismuth, 1982 (Lampione) and by Grasso and Pedley, in press (Lampione and Lampedusa) who have proposed a new lithostratigraphic scheme.

\section{Lithostratigraphy of Lampione and Lampedusa}

Eocene: According to Bonnefous and Bismuth (1982) the entire $36 \mathrm{~m}$ of exposed Lampione succession can be placed within the Lutetian to Priabonian division of the Eocene. This is principally on the basis of the contained foraminifera. They related the succession to the Halk el Menzel Formation of Tunisia. In contrast Segre (1960) concluded that the Lampione carbonates were Jurassic in age and Borsetti and Colantoni (1973) assigned them to an early Cretaceous age. The inner shelf wackestone and packstone associations are frequently dolomitized, although they contain an abundant miliolinid foraminiferal assemblage.

Miocene: Segre (1960) proposed a lithostratigraphic and structural scheme for the island of Lampedusa which has now been replaced by the work of Grasso and Pedley (in press). Faunas are not diagnostic of precise age in this shallow marine to peritidal succession, however, it appears most probable that the sequence is entirely Upper Miocene in age.

References to similar sequences in S.E. Sicily and the Maltese Islands strongly indicate a Tortonian to Lower Messinian age for the Lampedusa carbonates.

The following members and beds have been defined and are ascribed to the Lampedusa formation (Fig. 2):

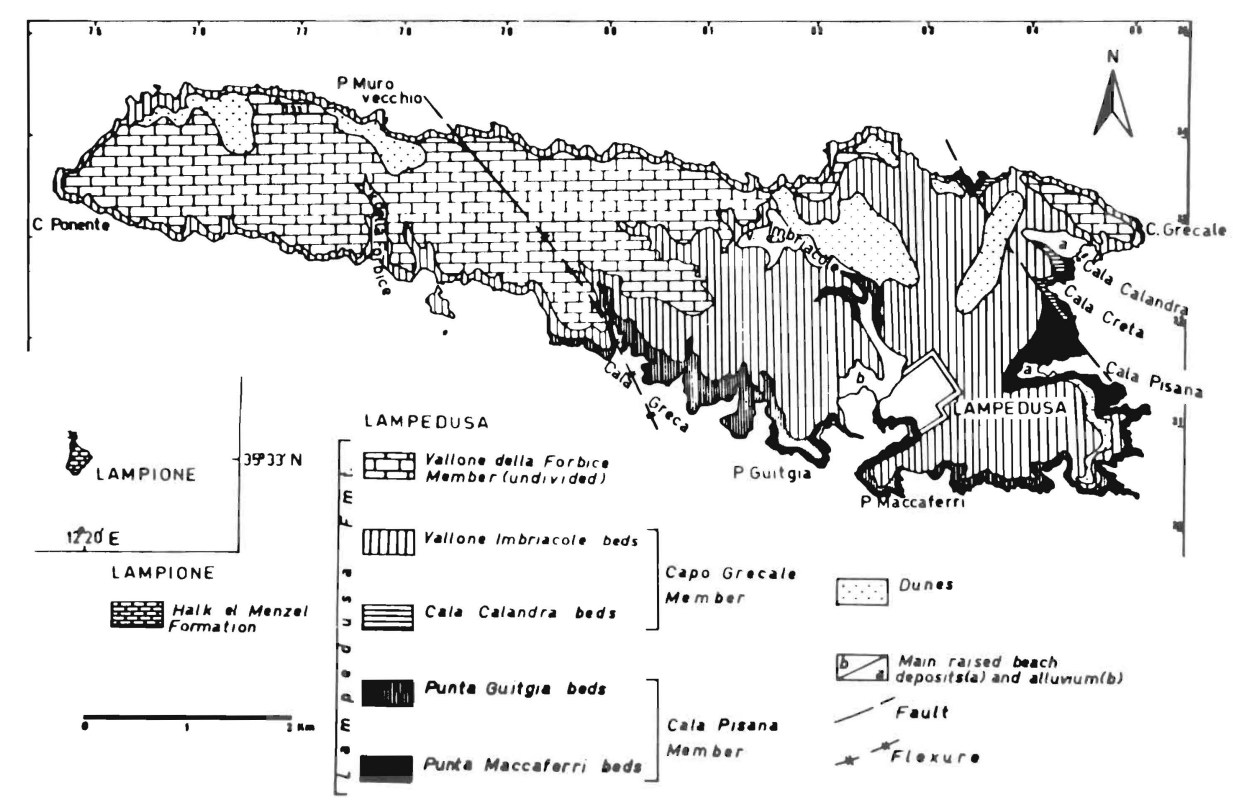

Fig. 2. Geological map of Lampedusa and Lampione (after Grasso and Pedley, in press). 
(1) Cala Pisana Member This is the oldest member in the succession and occurs in eastern coastal sections and in the Imbriacoli Valley. It extends down to an unknown distance below the sea level. The member is subdivided into two lateral facies of about equivalent age. To the east of Lampedusa Harbour occurs the Punta Maccaferri Beds, consisting of an extensively developed patch-reef sequence with associated algal-rich flanking sediments $(c .11 \mathrm{~cm})$. The western limit of these beds is marked by a strong development of fringing Porites reef. Packstones and peloidal grainstones dominate the off-reef sequence whereas the patch-reefs are typically composed of pale-cream carbonate mudstones containing pockets of bivalves. The off-reef sediments are rich in Borelis melo melo.

The Punta Guitgia Beds occupy western sites (Fig. 2) and about $5.3 \mathrm{~m}$ are visible above sea level. The beds consist of packstones, rhodolitic algal levels and oolitic grainstones, the latter extending eastwards to form a thin veneer above the Punta Maccaferri beds. The Punta Guitgia Beds represent a forereef carbonate ramp which progrades westwards.

(2) Capo Grecale Member This intermediate member of the Lampedusa sequence approximates to the "Facies di Craie" of Segre (1960). It lies unconformably above the Cala Pisana Member in areas east of Lampedusa village but is conformable westwards. It comprises two contrasting bed associations of which the Vallone Imbriacoli Beds are laterally most extensive (Fig. 2). This $18 \mathrm{~m}$ cream to white carbonate mudstone and wackestone sequence "Calcari farinosi bianchi" of Segre (1960) is now recrystallized to micro-dolomite with extensive mouldic porosity. Macrofaunas are sparse although pectinids occur in the Imbriacoli Valley and mounds of reef derived debris are present south of Cala Pisana. Lower levels contain abundant coralline algal debris, miliolinid foraminifera and Borelis melo melo.

The overlying Cala Calandra Beds comprise the second lithofacies, however, they are entirely restricted to the area immediately adjacent to the Cala Creta Fault on its eastern, downthrown, side. The beds consist of $8 \mathrm{~m}$ or more of thinly bedded, palebrown, wackestones and packstones which contain current-orientated cardiid bivalves especially in the upper levels. These beds directly overlie a thin marl and slumped yellow basal Vallone Imbriacoli beds and appear to be a syntectonic facies development associated with movement on the Cala Creta Fault.

(3) Vallone della Forbice Member This youngest member of the Lampedusa succession is c. $60 \mathrm{~m}$ thick and is the approximate equivalent of the "Calcari stratificati" of Segre; (1960). Outcrops are restricted to northern and western areas of the island with the best sections being accessible only in the deeper valleys. The sequence is predominantly pale-grey dolomitic packstones and pure dolomites which occur in $1-3 \mathrm{~m}$ thick beds. About $25 \mathrm{~m}$ above their base is a $4 \mathrm{~m}$ grainstone level with some oolitic grainstone levels associated with a coral patch-reef horizon. The member reflects sedimentation on a shallow sheltered platform which occasionally shallowed to shoalwater conditions. The development of a low diversity bivalve assemblage in the youngest levels together with a low coral diversity patch-reef associated with the grainstone level points towards an Early Messinian age (Esteban, 1979) although Late Tortonian is equally likely.

The youngest deposits of the island consist of Quaternary valley fills and raised beaches, often lying above planation surfaces, and aeolian dunes which are best developed in central northern parts of Lampedusa. No Pliocene strata are recorded. 


\section{Upper Miocene synsedimentary tectonics}

The island of Lampedusa shows clear evidence of syntectonic sedimenation which is thought to date back at least to Tortonian times. The majority of the syntectonic sedimentary features are directly related to movement about the Cala Creta Fault in eastern Lampedusa and directly affect the Cala Pisana member and basal part of the Capo Grecale member.

The Cala Creta Fault exhibits sinistral oblique movements associated with synsedimentary second order shear structures (Fig. 3a). Shear fractures inclined at $10^{\circ}$ to the master fault form a complex Riedelshear pattern on the wave cut platform at Cala Creta (Fig. $3 b$ ). The mega tension fractures ( $F$ on Fig. 3a) form an angle of about $30^{\circ}$ with the master fault and are interpreted as rotated Riedelshears with a vertical throw up to one meter. The conjugate Riedelshears trend $80^{\circ}-90^{\circ}$. The kinematics of Riedelshearing in comparison with the Riedel (1929) experiments are discussed in Reuther (1983).

Neptunean dykes are found in all three above mentioned fracture sets associated with the Cala Creta Fault. Generally they consist of pale cream wackestone but may occasionally consist of white micritic sediment. Those dykes associated with the $80^{\circ}-90^{\circ}$ trend are clearly seen to be truncated beneath the lowermost Vallone Imbriacoli Beds (basal Capo Grecale Member) in the S.E. coastal region of the island. These dykes show maximum widths of $20 \mathrm{~cm}$, the largerst on the island.

The neptunean dykes can readily be correlated with a unique bed of identical lithology which occupies the base of the Capo Grecale member in all parts of the island. This bed averages $2-3 \mathrm{~m}$ in thickness and provides a valuable lithostratigraphic marker horizon. It can therefore be argued that the three principal fracture sets to the Cala Creta Fault are all approximately contemporaneous in age. Furthermore, a well exposed synsedimentary breccia occurs in association with slumped yellow wackestones at the base of the Cala Creta Fault (Fig. $3 \mathrm{~b}$ ). This probably reflects downwarping of Vallone Imbriacoli Beds east of the fault shortly after initiation of synsedimentary movement. The down-warping of these strata represent the dip-throw component of the general sinistral oblique motion along the Cala Creta Fault. The unique horizon of Cala Calandra Beds immediately succeeds the slumped beds and breccia and is virtually restricted to areas east of Cala Creta Fault. It consists of thinly bedded, relatively coarse-grained sediment forming a prism against the fault plane. These strata almost certainly represent a gravity slide of bioclastic sediments and debris flow deposits derived from the west. It now occupies the palaeo-trough generated by the Upper Tortonian movement of the Cala Creta Fault (Fig. 3c).

The progression of tectonic movement during the Upper Miocene in Lamped 1 is well reflected in the development and distribution of lithofacies sequences. Initiany, sedimentation was controlled by a marked NE - SW slope break extending through Lampedusa harbour. A fringing Porites reef developed at the shelf slope break between fore-reef carbonate ramp (rhodolitic algal and bioclastic wackestones and packstones of the Punta Guitgia Beds) and the patch-reef dominated inner shelf(Punta Maccaferri Beds). Arching in the latter area is responsible for the generation of marine planation surfaces at several levels in this back-reef inner shelf area. These principally affect the top of the Punta Maccaferri Beds west of the Cala Creta Fault line. It is the application of a ESE-WNW to SE-NW orientated $\sigma \mathrm{h}$ max compression which is responsible for this arching and related erusion (Fig. 3a). 

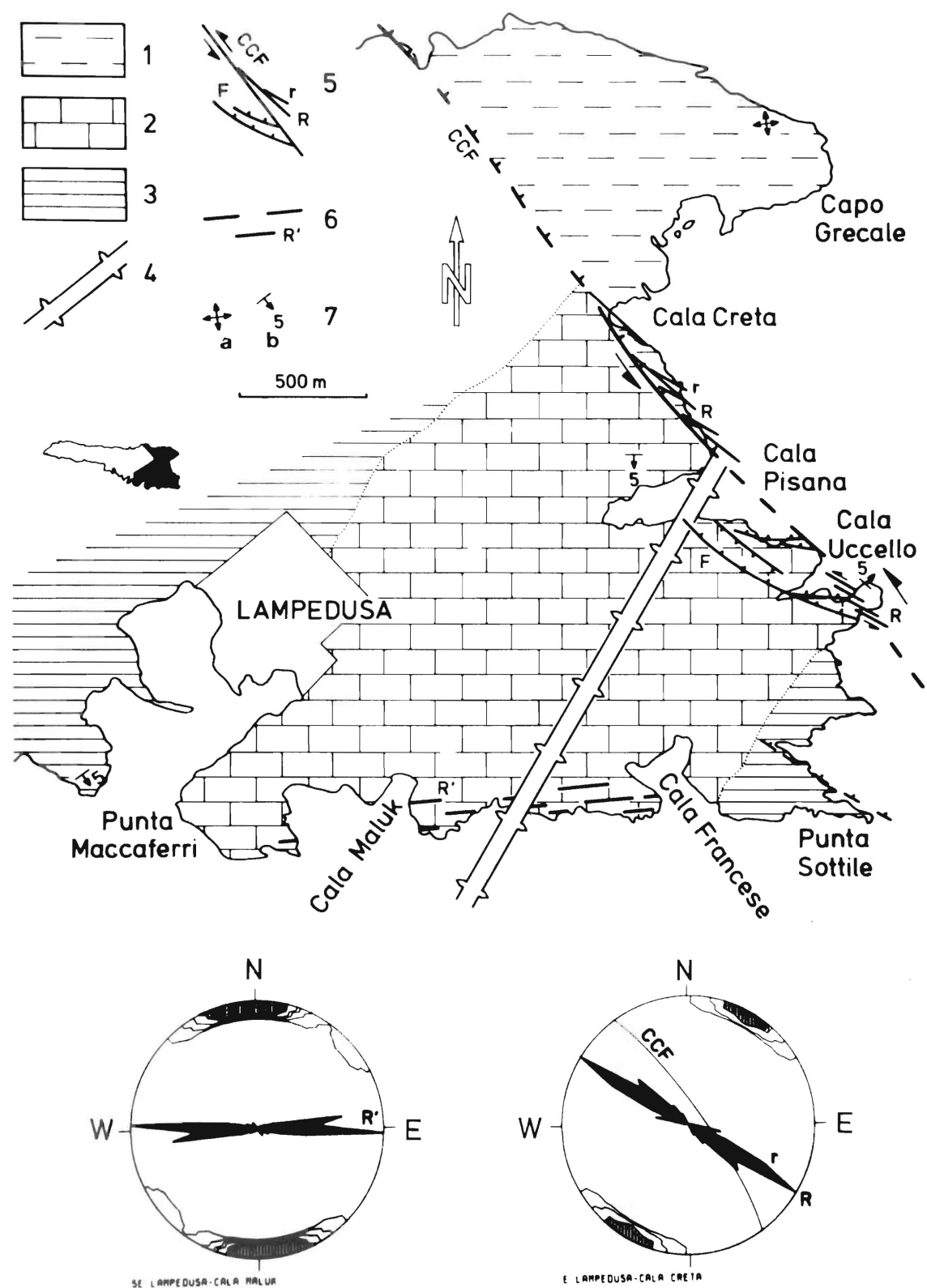

Fig. 3a. Facies distribution on East Lampedusa caused by synsedimentary Upper Miocene movements: 1) Downwarped area with increased thickness of the Capo Grecale member due to growth faulting; 2) Reef flat area of Punta Maccaferri Beds; 3) Algal and bioclastic carbonate ramp to the foot of the reef wall, Punta Guitgia Beds; 4) Axis of syndepositional up-arching; 5) Cala Creta Fault $(\mathrm{CCF})$ with second order faults: $\mathrm{R}=$ Riedelshears, $r=$ Riedel within Riedelshears, $\mathrm{F}=$ Megatension joints; 6) $\mathrm{R}^{\prime}=$ Conjugate Riedelshears at places represented by Neptunean dykes; 7) horizontal strata (a) and dipping strata (b) in degrees. The two Shmidt diagrams, lower hemisphere, show the distribution of the Riedelshears $(R)$ and Riedel within Riedelshears (r) along the Cala Creta Fault (CCF)-lower right-and of the conjugate Riedelshears ( $R$ ) in the Cala Maluk area along the SE coast - lower left. (circle diameters left $=30 \%$, right $=25 \%$ ). 


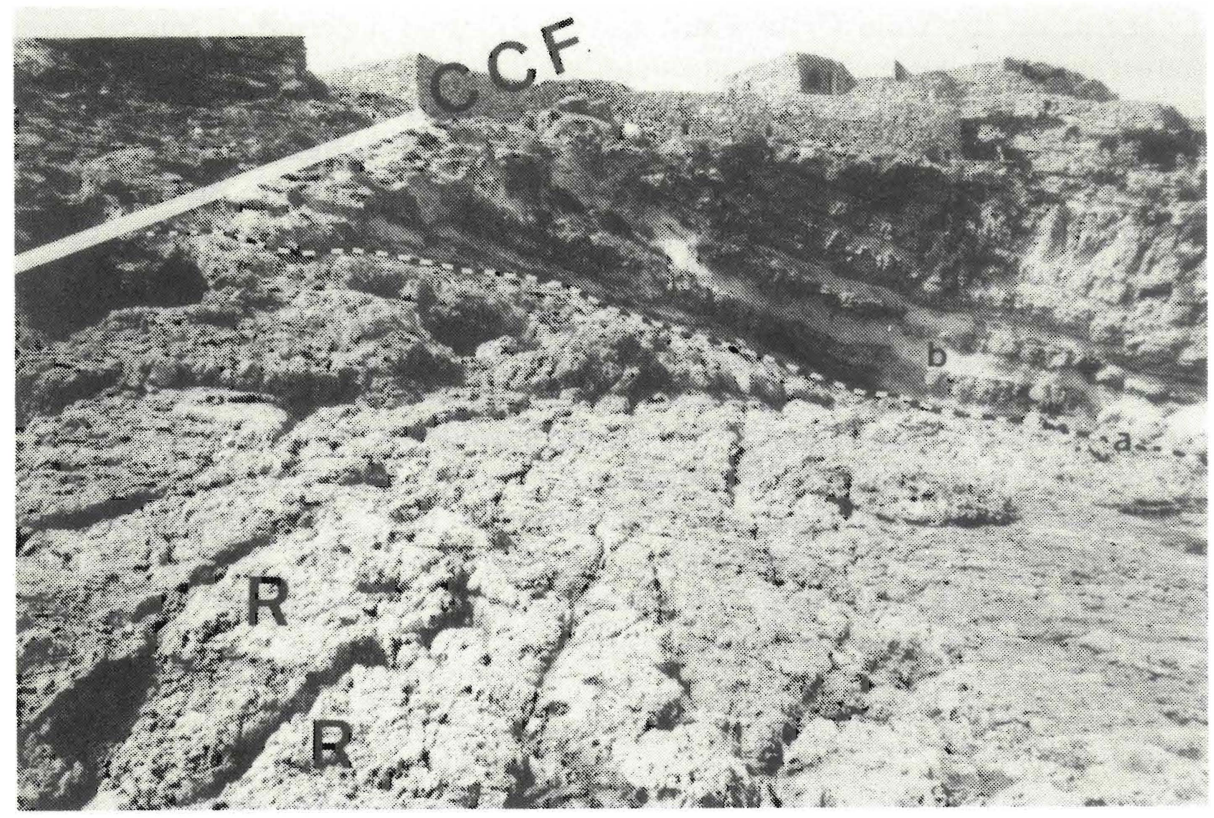

Fig. 3b. Cala Creta Fault (CCF) and second order faults illustrated in Fig. 3a. Contact between brecciated patch reefs of the Punta Maccaferri Beds (Cala Pisana Member) below, and allochthonoous Cala Calandra Beds (Capo Grecale Member) above. The mutual contact lies at a. Synsedimentary fracturing and slumping severly disrupts the lower levels of the Cala Calandra Beds (b).

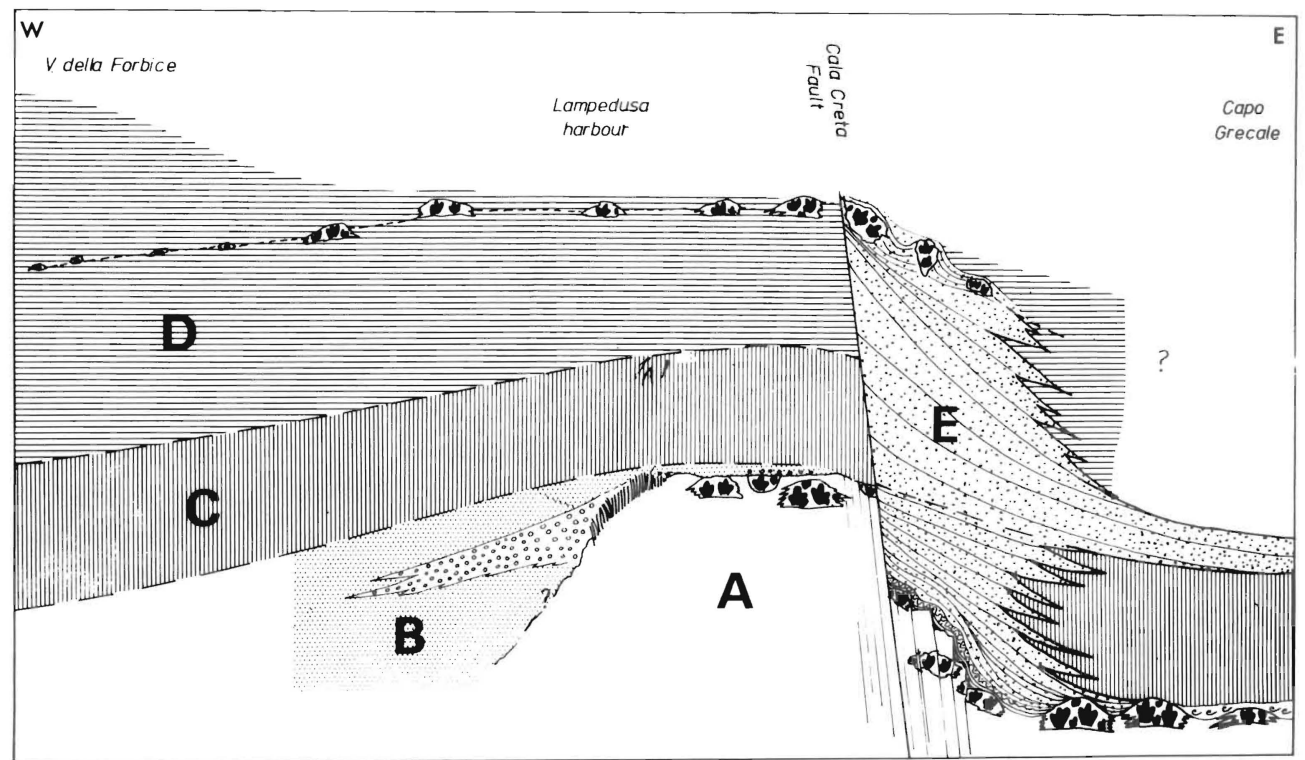

Fig. 3c. E-W profile reconstruction of the lithofacies distribution within the Miocene carbonates of Lampedusa: A, Punta Maccaferri Beds; B, Punta Guitgia Beds; C, Capo Grecale Member; D, Vallone della Forbice Member. The effects of synsedimentary movement along the Cala Creta Fault are demonstrated by the expanded sequence of Cala Calandra Beds (E) which are not recorded west of the fault line (see also Fig. 2). 
Movement on the Cala Creta Fault clearly followed a period of compression of unknown duration but one which profoundly affected the development of lithofacies associated with the oldest exposed units. The first movement occured after early submarine lithification of the inner shelf patch-reef, which suffered extensive shattering adjacent to and immediately east of the fault line. Slumping of the immediately overlying yellow wackestones (Capo Grecale Member) east of the Cala Creta Fault and the incorporation of these beds into the open fractures of the Cala Pisana Member suggests several episodes of movement on the Cala Creta Fault during its early development. The apparent inclusion of reefoidal olistoliths or partially displaced reef high in the Cala Calandra Beds, well seen along the N. coast of the island (see Figs. 2 and 3c) points to another movement episode affecting the Cala Creta Fault during middle Vallone della Forbice Member times. This episode is recorded west of the fault line by the establishment of a thin sequence of intertidal patch-reef, oolitic grainstones and bioclastic packstones in an otherwise deeper shelf sequence. The implications are that regional uplift was associated with this latest recorded episode of Miocene fault movement.

\section{Linosa}

The stratigraphy of the volcanic sequence of Linosa has been studied by Messerli (1958), Segre (1960) whose work was amplified by the more detailed data of Di Paola (1973), and Haas and Hammermann (1983).

The exposed stratigraphic succession, according to Segre (1960) and Di Paola (1973), consits of three main units which can be referred to three distinct cycles of volcanic activity. According to Barberi et al. (1960) the age of this activity is not older than $1 \mathrm{M}$.Y.

The oldest volcanic products, placed by Segre (1960) in the first cycle, crop out in the southeast of the island at Cala Pozzolana di Levante. They consist of well bedded greyish tuffs having a high frequency of xenoliths of the presumed underlying magmatic rocks.

To the same cycle Segre (1960) assigned the thin bedded yellow pyroclastic tuffs cropping out on the western side of the island, at Cala Pozzolana di Ponente. They probably represent the remnant of a big pyroclastic cone now in part destroyed by the sea. Both these outcrops contain basaltic dykes cutting pyroclastic products. Additionally the top is marked by an erosional surface (Fig. 4) pointing to a period of volcanic inactivity between the first and following volcanic cycle.

The intermediate cycle of volcanic activity produced a series of greyish tuffs with alternating horizons of ashes and thin bedded volcanic sands. These are associated with well preserved explosive vents (Fig. 5a) and parasitic spatter cones and together form a band across the center of the island.

The products of both the older and the intermediate cycle exhibit structures typical of pyroclastic flow deposits (see Wohletz and Sheridan, 1983 for detailed references). We emphasize here that these structures, hitherto unrecognized on the island except for passing reference in Di Paola (1973), point to the explosive character of the magma. The extrusions are products of phreatic eruptions into shallow marine or subaerial environments. Some of the structures found show close analogies withthose associated with base surge pyroclastics (see Schmincke et al., 1973); examples are given in Figs. 5b and 5c. In addition, the explosive mechanism of the Linosa pyroclastics closely parallels that of the basalt volcanoclastics of the Hyblean region of SE Sicily (Grasso et al. 1979, 1982; Carbone and Lentini, 1981) and the andesitic to rhyolitic pyroclastic 


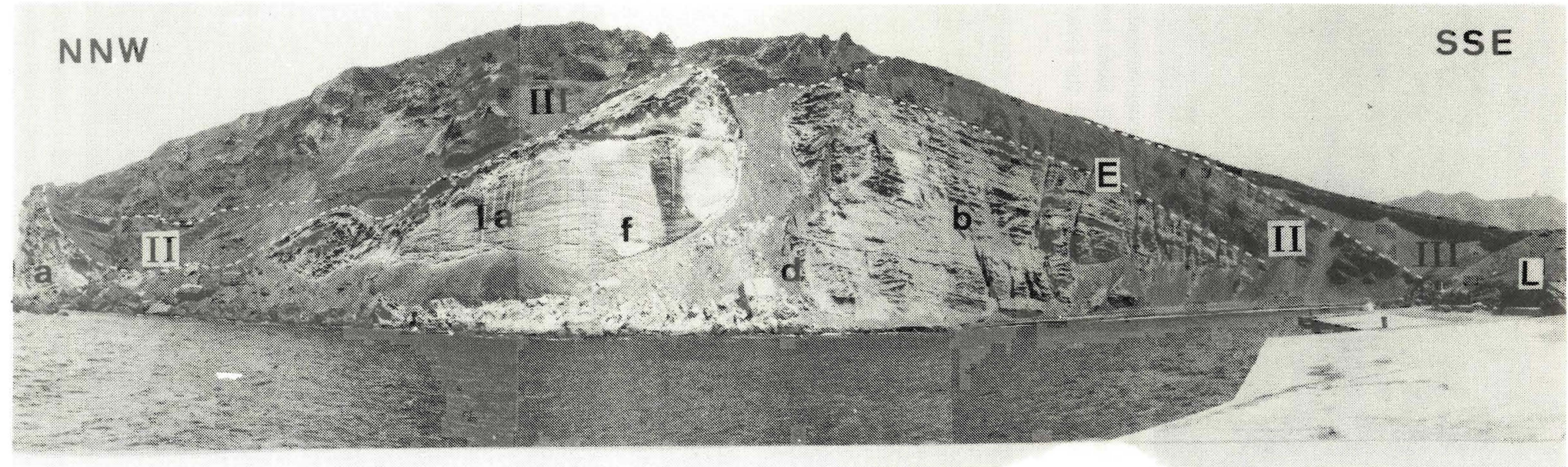

Fig. 4. Linosa W-coast, Montagna di Ponente. The products of three volcanic cycles are exposed: I, thin-bedded yellow pyroclastic tuffs (a) exhibiting normal faulting (f) and green tuffs (b) with basaltic dykes (d); II, Scoriaceous lavas and black lapilli; III, Mainly subaerial products as scoriaceous flows and thin-bedded red and yellowish to greyish ashes and lapilli; L, lava flow extending up to the SW coast. A well pronounced erosional surface (E) divides cycle II from cycle I; a further minor erosional unconformity is developed between II and III. 


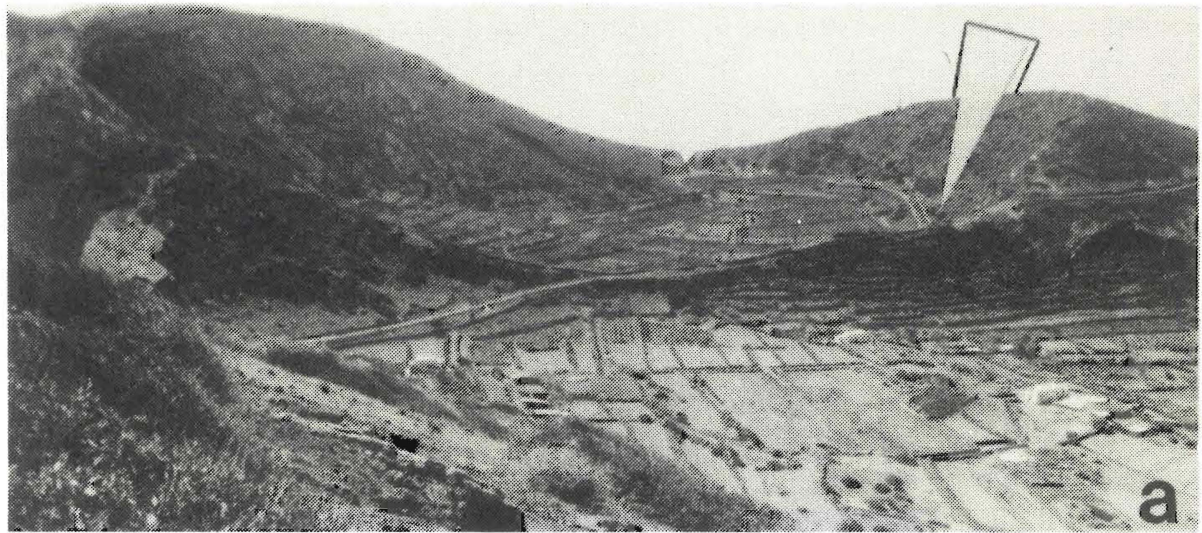

Fig. 5a. The Caldera Centrale (foreground, diameter 500m) and Fossa Cappellano (background, diameter $300 \mathrm{~m}$ seen from Monte Vulcano looking towards the South. Both form funnel-shaped craters filled with explosive volcanoclastics. The white arrow indicates the location of the air-fall feature shown on Fig. 5b.

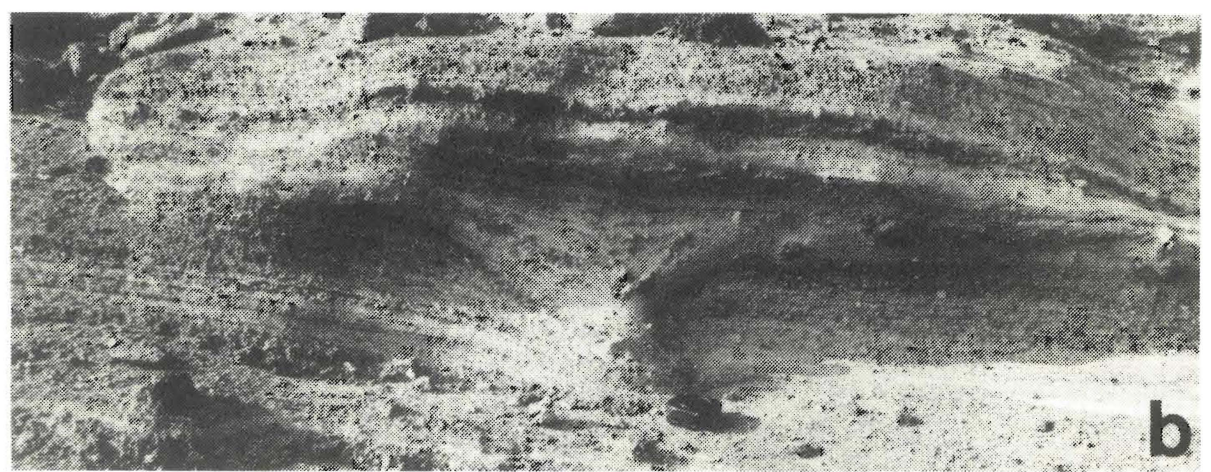

Fig. 5b. Impact deformation of air-fall origin.

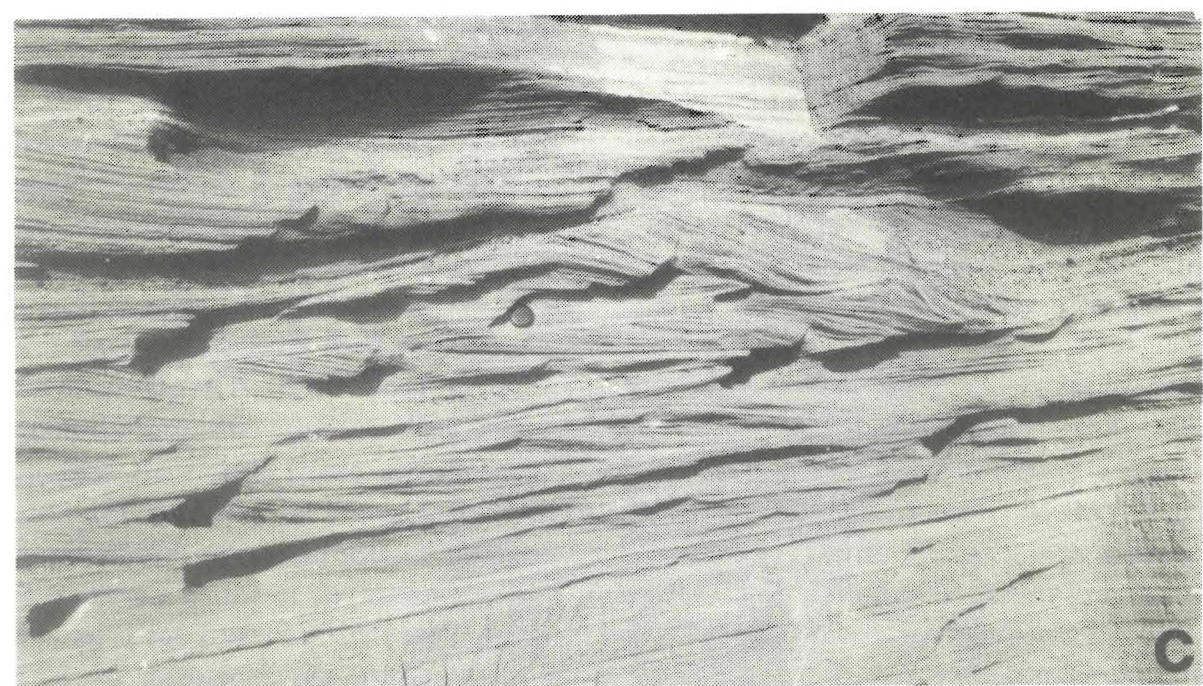

Fig. 5c. Cross lamination connected with sandwave forms (antidunes). Cala Pozzolana di Ponente (localization on Fig. 7). 
deposits of the Aeolian Islands (Crisci et al. 1981).

The perimeter of the island is covered, except for a small stretch on the south east coast, by large basaltic lava fields and associated spatter cones within which, at places, the superimposition of several flows (five flows at Scogli dei Bovi Marini on the NE side) can be recognized. They have provided a protective cover over the softer tuffs reducing marine erosion.

The volcanic products of Linosa show an undersaturated alkali basalt fractionation trend, characteristic of volcanoes located on graben margins (Di Paola, 1973; Haas and Emmermann, 1983).

Although principally volcanic, the deposits of the island contain considerable numbers of lithic carbonate bombs. These range in colour from pale-grey to cream and, upon thin section examination are found to be mainly wackestones (rarely packstones) typical of a shallow, fully marine shelf setting. Several samples examined contained miliolinid foraminifera associations suggesting lagoonal or inner shelf locations. All, however, appear to be Tertiary in aspect although no precise age could be ascribed to them.

\section{Neotectonics}

The mechanism leading to the fault processes observed in the Upper Miocene on Lampedusa is considered to be responsible also for the neotectonic fault development. Unfortunately no Pliocene deposits are known from the exposed shoulders of the Pantelleria Rift to show the transition from synsedimentary Upper Miocene movements into the Quaternary. On Linosa however the young volcanic products are coupled with structures of the same NNW-SSE and WNW-ESE tensional features seen on Lampedusa.

\section{Lampedusa and Lampione}

Pleistocene neotectonism has played a major role in both morphological control and in modification of pre-existing tectonic styles through the reactivation of previous faults and in regional tilting and flexing of strata. Fig. 6 illustrates the principal morphological features which are considered to have been influenced in their development by neotectonic movement.

The Cala Creta Fault shows later superimposed vertical oblique slickensiding on calcite infilling where it is exposed in the Cala Creta area. Additionally, normal movements are indicated on the fault plane where the fault cuts the steep cliff on the northern coast of the island. The minor faults and joints associated with the Upper Miocene faulting episode appear to have had a marked influence on the younger stream courses and this is best illustrated in the middle and upper regions of the Vallone Imbriacoli and in the valleys to the west. Marked steps are produced in the watercourse profiles where these fractures cross. This may indicate later neotectonic movement along these pre-existent features with insufficient time for erosion levelling by the present intermittent water flow.

A NW-SE trending Upper Miocene fault, dipping eastwards, visible on the north coast, at Punta Muro Vecchio, is intimately associaed with younger movement along its southerly monoclinal extension. This movement has had a profound influence upon the distribution of many of the Quaternary and Recent features of the Island. The monocline passes out to sea at Cala Greca, however, a low amplitude anticline offshoot 


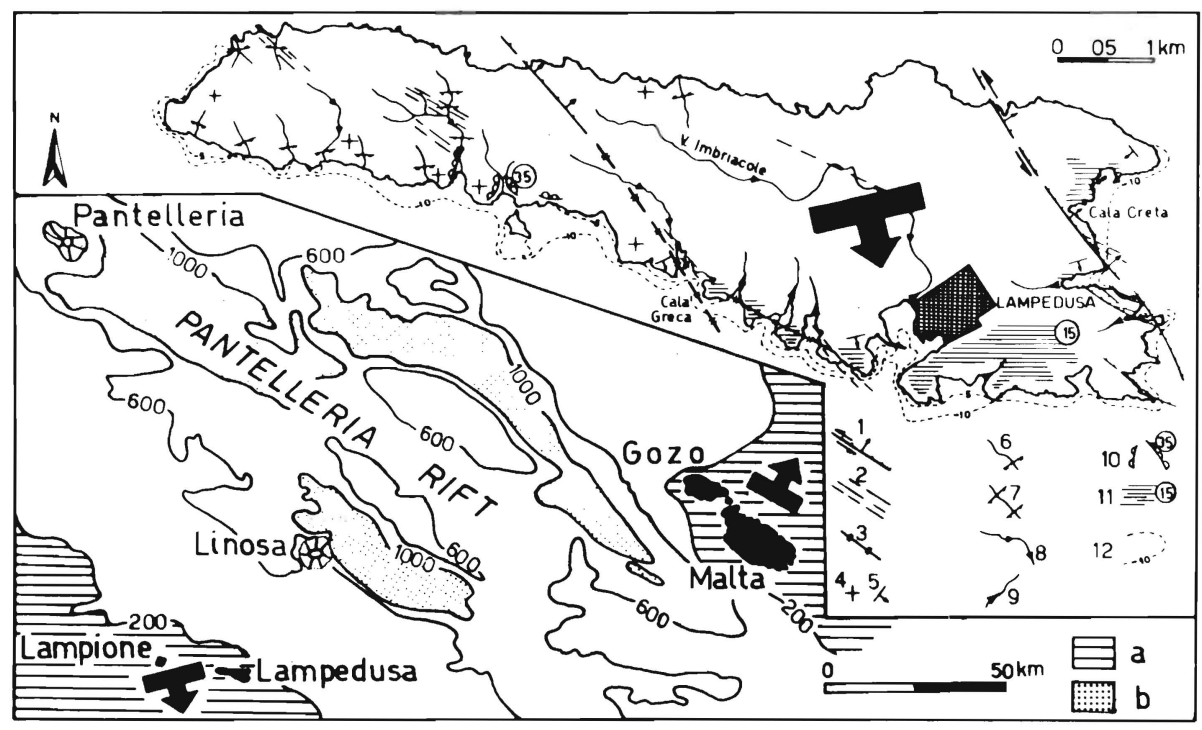

Fig. 6. Neotectonic map of Lampedusa. 1) Oblique slip to normal faults of the Cala Creta Fault system: 2) Fractures controlling valley deflection; 3) Monoclinal flexure; 4) Horizontal strata; 5) Dipping strata in degrees; 6) Hanging valleys; 7) Steps in talwegs; 8) Deflected valleys; 9) Inundated river mouths; 10) Ancient sea caves; 11) Marine terraces (Tyrrhenian); 12) Isobaths, in metres, to show seaward continuation of drowned valleys of East Lampedusa. The black strike bar and dip arrow indicate the tilt of the island as inferred from the above mentioned neotectonic features. Inset map: The southerly directed block tilting of Lampedusa compliments a nearly opposite NE tilting observable on the Maltese Islands. Both tilts are caused by the still active upwarping of the graben shoulders. (a) graben shoulders; (b) individual graben segments of the Pantelleria Rift.

affects all strata in the southern peninsulas as far east as Lampedusa village.

The monoclinal flexure divides the island into two morphological units. To the west all strata are horizontal and vertical cliffs bound the promontory. Almost all water courses terminate seawards as hanging valleys. To the east, the northern coastline features permit close comparison with the western promontory, however, the southern and south-eastern coastline is of ria-type with well developed drowned river valleys. This suggests neotectonic movement of the monocline with a pivot point on the fault line close to the north coast of the island. Superimposed Tyrrhenian (Late Pleistocene) features and sediments in the valleys indicate that this movement was completed by late Pleistocene times. Associated molluscan faunas, including Strombus bubonius, help to date these deposits (Segre, 1960); east of the monocline, in the ria-coastline areas (Fig. 6) these Tyrrhenian features consist of marine abrasion surfaces and raised beach deposits (e.g. Cala Creta). All appear to be related to a single planation surface lying at about $15 \mathrm{~m}$ OD which can be traced intermittently from Cala Greca eastwards to Cala Creta. In contrast, the western promontory west of the monocline lacks such planation surfaces, however, sea caves along lower watercourses and along the coastline also of Tyrrhenian age (Segre, 1960) occur to a maximum elevation of $35 \mathrm{~m}$ OD.

It is suggested that both the caves and the marine planation surfaces are related to the same episode. Both have resulted from two contrasting uplift rates east and west of the monoclinal flexure dividing the island. Clearly, while rapid headward erosion has destroyed much of the original pre-Tyrrhenian coastline in the western promontory 
and northern coast, no such destruction of the southern and souteastern coastline has occured. This conclusion is supported by the bathymetic contours around the presentday coastline which clearly show a submarine extension to the drowned ria valleys.

A final confirmation for a pre-Tyrrhenian age for the monoclinal flexuring comes from the ria valleys themselves which, in the Cala Creta area, are filled with Tyrrhenian raised beach deposits.

Post-Tyrrhenian neotectonism is readily demonstrated by the height of $15 \mathrm{~m}$ OD of the Tyrrhenian terraces east of the monocline and by the height of $35 \mathrm{~m}$ OD of the ancient sea caves in the western promontory. The two are considered to have developed originally at the same sea level. The present $20 \mathrm{~m}$ average difference in elevation between terraces and ancient caves must indicate approximately the amount of postTyrrhenian movement on the monclinal flexure.

The black strike bar and dip arrow (Fig. 6) demonstrate the regional tilt of Lampedusa which is derived from a consideration of all the data previously presented. This tilting manifests itself in the distribution of topographic elevation within the island. Thus the occurrence of Eocene strata on Lampione islet is not random but is governed by the same regional dip established for Lampedusa. The inset map in Fig. 6 shows that the southerly tilting of the island of Lampedusa compliments an opposite NE tilting of the Maltese Islands (Illies, 1980). This oppositely directed tilting is attributed to still active shoulder upwarping on both sides of the Pantelleria Rift. Associated mantle updoming (Fig. 8) and crustal thinning (Colombi et al., 1973) lead to graben development and widespread volcanism.

\section{Linosa}

On Linosa Island different neotectonic events are distinguishable. As shown by Di Paola (1973) the craters of Montagna di Ponente (M. Nero and M. Timpone), Fossa Cappellano and M. Cacarella form a WNW to ESE trending belt (Fig. 7) and represent the most important period of volcanic activity, governed by tensional tectonics, which led to the formation of the island. Vertical displacements within the yellow thin-bedded tuffs belonging to the first volcanic cycle exposed on the western slope of Montagna di Ponente (Segre, 1960) are orientated N $10^{\circ} / 60^{\circ} \mathrm{E}$ (Fig. 4). These displacements, with a throw of only $50 \mathrm{~cm}$, are interpreted as volcano-tectonic collapse structures which were probably contemporaneous with the basaltic ring dykes emplaced at the end of this volcanic cycle. The erosional surface at the tope of this pyroclastic sequence ( $E$ in Fig. 4) cuts both the faults and the dykes.

During a later tectonic period, the circular explosive vent between $\mathrm{M}$. Timpone and Fossa Cappellano was cut in the south by a N $100-100^{\circ}$ trending fault which has also affected the recent southern slope of $\mathrm{M}$. Vulcano. A parallel normal fault dipping south and two basaltic dykes of the same trend cut through the greyish tuffs of the southern slope of M. Calcarella ( $f, d$ in Fig. 7 and on the Schmidt diagram). The greyish tuffs are intensively disrupted by long calcite infilled tension joints up to $5 \mathrm{~cm}$ wide parallel to the fault.

The eastern part of the island is characterized by $\mathrm{N} 145^{\circ}$ trending structures. A $2 \mathrm{~m}$ wide basaltic dyke of this direction cuts the greyish tuffs of the M. Calcarella (see the Schmidt diagram in Fig. 7).Normal faults with the same strike cut the western slope of Montagna Rossa displacing by at least $20 \mathrm{~m}$ the topmost volcanic levels of this volcano. In the Schmidt diagram in Fig. 7 the two main structural trends of the Pelagian islands can be recognized. Both the $\mathrm{N} 100^{\circ}$ and the $\mathrm{N} 140^{\circ}$ trends 

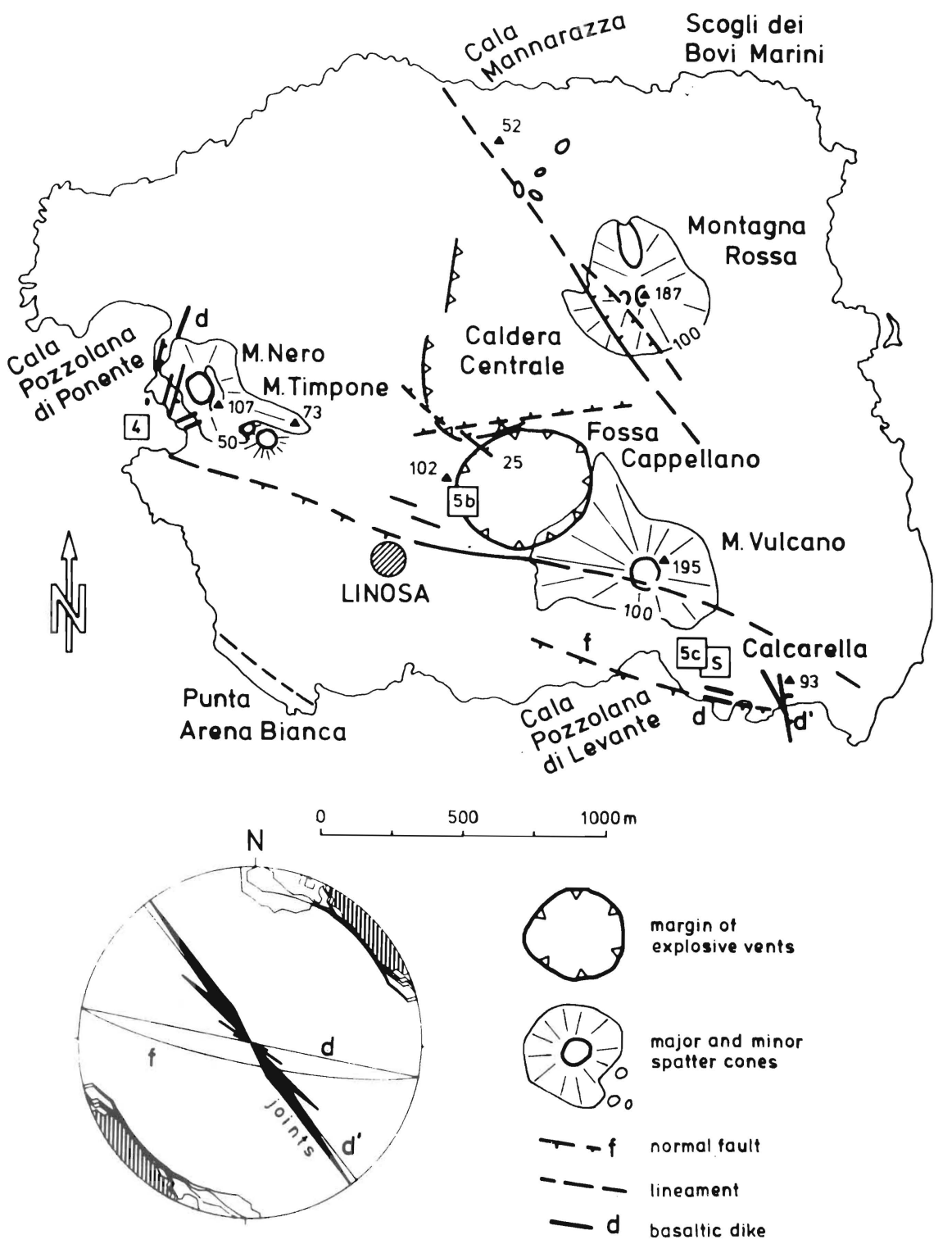

Fig. 7. Neotectonic structures and associated volcanic features on Linosa Island. The insets show the locations of Figs. 4, 5b, 5c and S (site of measurement for the Schmidt diagram on the lower left: circle diameter $=36 \%$ ). The Caldera Centrale and Fosso Cappellano craters are shown on Fig. 5a. 


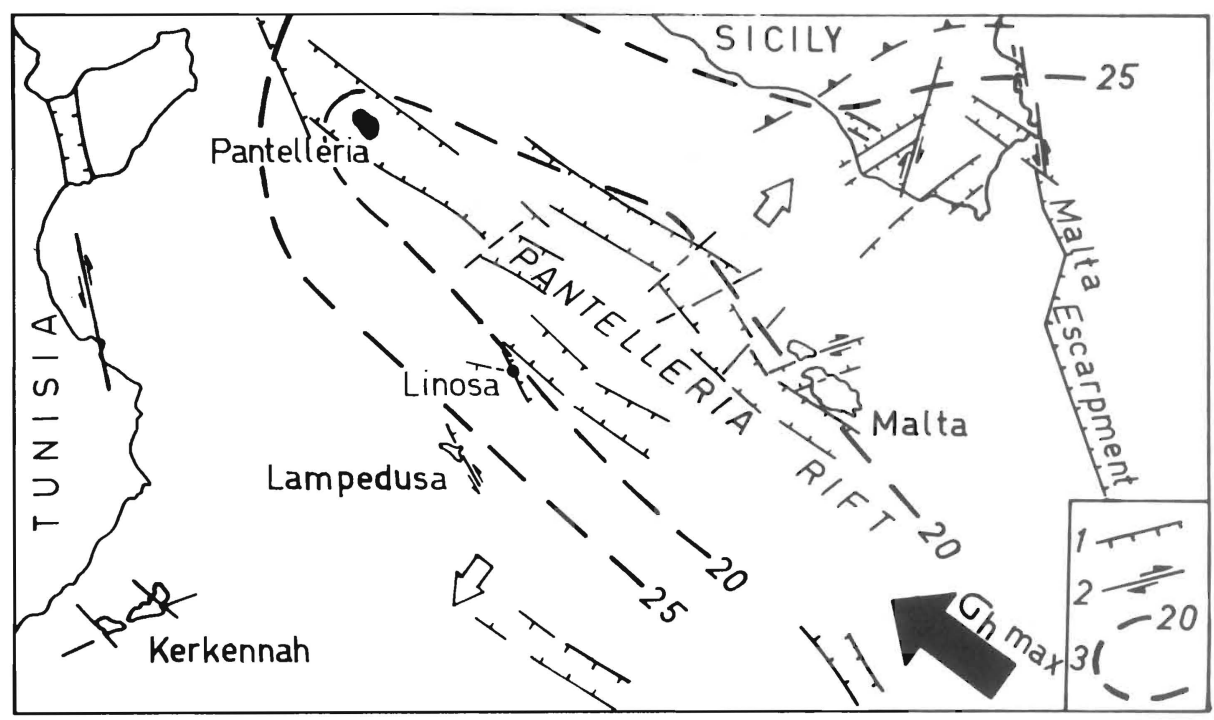

Fig. 8. Neotectonic sketch of the Pantelleria Rift (Central Mediterranean Sea) 1) Normal faults; 2) Relative sense of horizontal movements along wrench faults; 3) Depth of Moho in km (after Boccaletti et al., 1984). Black arrow shows direction of the maximal horizontal compression ( $\sigma \mathrm{h}$ max) inferred from field data on the graben shoulders. White arrows indicate sense of spreading. Further explanations of symbols is obtained in Fig. 1.

exhibit tensional structures with a dyke $(d)$ and a normal fault $(f)$ in the first direction and tension joints and a further dyke $\left(d^{\prime}\right)$ in the second direction. The tension along this part of the Pantelleria Rift can be implied to have originated either parallel to the NWSE trending direction of maximal horizontal stress (Fig. 8) associated with normal faulting or as tensional, second order effects attributed to the NNW-SSE main sinistral shear movements.

\section{Tectonic outline of the Pelagian Block in relation to the structural development in the Central Mediterranean Sea.}

\section{The Pelagian Islands}

Lampedusa and Lampione lie at the eastern extremity of the Tunisian Platform on the SW shoulder of the Pantelleria Rift. This rift system consists of a group of deep, NW-SE orientated troughs arranged en echelon (see Fig. 1). The troughs are both physiographic and tectonic depressions in which unusually thick Plio-Quaternary sediments occur (Colantoni, 1975; Winnock and Bea, 1979).

The island of Linosa is a rift-type emergent volcanic sea-mount lying on the homocline to the SW margin of the Linosa basin (Di Paola, 1973) which intersects $\mathrm{N} 100^{\circ}$ trending structures.

\section{The Maltese Islands}

The Maltese islands lie on the NE margin of the Malta Basin. Sedimentologically, the Maltese islands and Lampedusa are both associated with the relatively stable carbonate platform of the Pelagian shelf. Reef building episodes in the Tortonian of 
Lampedusa can be directly correlated with analogous Tortonian reef tracts described from Malta (Pedley 1979, 1983). Tectonically, there is also much in common between the two islands. In Malta two dominant fault trends are developed (Pedley et al., 1976). The Victoria Lines Fault systems consist of $\mathrm{N} 60^{\circ}-80^{\circ}$ trending normal faults which were preceded by synsedimentary tensional tectonics beginning during the Lower Miocene (Illies, 1980) and continuing up to Late Tortonian times (Bosence and Pedley, 1982). The main graben formation occurred after Upper Miocene. Some of these faults (e.g. in the Comino Strait between Malta and Gozo) are neotectonically remodelled into dextral strike-slip faults (Illies, 1980; 1981; Reuther, 1983). The second Maltese fault system trends averagely $\mathrm{N} 120^{\circ}$ and is developed in south Gozo and, more particularly, along the southern coast of Malta (Maghlaq Fault complex). Here the Victoria Lines Fault system is developed as $\mathrm{N} 70^{\circ}$ trending series of normal faults, together with associated joints. Synsedimentary growth faulting trending $\mathrm{N} 70^{\circ}$ and $\mathrm{N} 120^{\circ}$ within the uppermost limestone formation of Malta indicates that both fault systems have been active during a distinct period in the Upper Miocene.

Illies $(1963,1980,1981)$ emphasized the neotectonic aspect and dip slip movement of the $\mathrm{N} 120^{\circ}$ trending Maghlaq fault plane, stressing its role as the easternmost master fault of the Pantelleria Rift. The beginning of subsidence which preceded the graben formation is of Upper Miocene age. Allodapic limestones originating from areas to the east of the present day Maghlaq fault are sandwiched between Tortonian shallow shelf and reefal limestones (Grasso and Pedley, in press). Further support for Tortonian synsedimentary movements is given from growth faulting observed in several places along the southwestern coast of Malta (Reuther, 1984a, b).

\section{General synthesis}

Clearly, the Tortonian tectonic episode of the Maltese Islands finds a close parallel with the similarly timed Lampedusa tectonic events. Both islands face each other across the Linosa and Malta basins and it appears likely that the two different fault trends, a $\mathrm{N} 145-160^{\circ}$ sinistral lateral wrench system on Lampedusa and a $\mathrm{N} 120^{\circ}$ dip slip system on the Maltese Islands both reflect the effects of a common stress regime in the central Mediterranean region, characterized by a direction of maximal horizontal stress of $\mathrm{N} 120^{\circ}-130^{\circ}$.

Increasingly, evidence from other sources shows that the central Mediterranean basins started to develop during Tortonian times and were controlled by the dominant $120^{\circ}$ trend of downwarping. Colantoni and Borsetti (1973) and Colantoni (1975) found from dredging subsea outcrops that the present shelf areas were already established and accumulating shallow water carbonates by the Upper Miocene whereas the modern basins are receiving pelagic sediments. Further confirmatory data for Linosa has been obtained from a petrological study of twenty lithic bombs within the emergent volcanic pile. All samples were exclusively of shallow water carbonate aspect and although none could be dated palaeontologically, several appear identical to lithofacies on Lampedusa (i.e. Vallone Imbriacoli Beds). All were presumably ripped up from shallow depth in the upper sedimentary substratum of the volcano and there is nothing to suggest an age other than Miocene.

The Lower Pliocene evidence for continued basin development is good. Colantoni and Borsetti (1973) and Colantoni (1975) recovered Trubi Formation (a pelagic micrite containing abundant planktonic foraminifera) exclusively from the basinal areas. Certainly, Trubi is absent from Lampedusa and Malta and has never been recorded by 
dredging from the offshore areas. Confirmation for tensional tectonics during Upper Miocene is given by Beccaluva et al. (1981) who recorded a K-Ar age of $10 \mathrm{MY}$ from basaltic rocks dredged from a volcanic seamount west of Pantelleria.

The development of a sinistral shear component on NNW-SSE orientated fault planes together with $120^{\circ}$ striking normal faults controlling graben development appears to have been active well into the Quaternary. In eastern Tunisia and the Kerkennah Islands a $\sigma_{1}$ direction of $130^{\circ}$ characterized the stress field up to recent times (Kamoun et al. 1980; Delteil, 1982). In central Tunisia NW-SE trending graben development started during Upper Miocene(Burollet et al., 1976). In Sicily Ghisetti and Vezzani (1980) and Di Geronimo et al. (1980) recorded a sinistral shear component to NNW-SSE fault planes believed to be of Middle Pliocene age. Furthermore, some coastal basins infilled by Quaternary sediments along the Ionian margin of the Hyblean Plateau (SE Sicily) are controlled by normal faults with an average trend of $120^{\circ}$ which have a development history ranging in age from Middle Pliocene to basal Pleistocene (Grasso and Lentini, 1982). These may be interpreted as Riedel-type grabens connected with sinistral wrenching along the NNW-SSE orientated fault planes which trend subparallel to the Malta Escarpment (Fig. 8).

As an extension to these considerations it is suggested that both the Malta Escarpment and the grabens within the Pantelleria Rift system are all part of a complex and interrelated tectonic system during Upper Miocene to Quaternary time.

The physiographic orientation of the long axes of the Linosa and Malta basins (Fig. 1) reflect the orientation of the controlling master faults (Fig. 8). Significantly, the orientation of these is virtually concurrent with the orientation of the $\mathrm{N} 120^{\circ}$ trending normal faults on the eastern side of the Hyblean Plateau (SE Sicily), with the N $120^{\circ}$ trending normal faults of the Maghlaq fault system (south Malta) and with the N $120^{\circ}$ trending fracture set of Lampedusa ( $f$ in Fig. 3a).

The contemporaneous development of the $\mathrm{N} 120^{\circ}$ trending Lampedusa extensional fractures with sinistral movement on the $\mathrm{N} 145^{\circ}-160^{\circ}$ trending Cala Creta fault during the Tortonian, forms a model for initiation of the Pantelleria Rift during Upper Miocene, at least in its southeastern part.

\section{ACKNOWLEDGEMENTS}

This study was supported by Italian M.P.I., Art. $6540 \%$ (Project coordinator Prof. F. Lentini, Istituto Scienze della Terra, Universitá di Catania) for M.G.; Royal Society Scientific Investigation Fund grant for H.M.P.; and Deutsche Forschungsgemeinschaft, SFB 108 Universität Karlsruhe, for C-D:R.

The Autors gratefully acknowledge Prof. Dr. A.E.M. Nairn (E.S.R.I., University of South Carolina, Columbia, U.S.A.) for critical discussion and helpful comments.

\section{REFERENCES}

Barberi, F.; Borsi, S.; Ferrara, G. and Innocenti, F. (1969) Strontium isotopic composition of some recent basic volcanites of the southern Tyrrhenian Sea and Sicily Channel. Contr. Mineral. Petrol. 23 (2): 157-172.

Beccaluva, L.; Colantoni, P.; Di Girolamo, P. and Savelli, C. (1981) Upper Miocene submarine volcanism in the Strait of Sicily (Banco Senza Nome). Bull. Volcanol. 44 (3): 573-581. 
Boccaletti, M.; Nicolich, R. and Tortorici, L. (1984) The Calabrian Arc and the Ionian Sea in the dynamic evolution of the Central Mediterranean. Mar. Geol. 55: 219-245.

Bonnefous, J. and Bismuth, H. (1982) Les faciés carbonatés de plateforme de l'Eocène moyen* et supérieur dans l'offshore Tunisien nord-oriental et en Mer Pélagienne: Implications paléogeographiques et analyse micropaléontologique. Bull. Cent. Rech. Explor. Prod. Elf-Aquitaine 6 (2): 337-403.

Borsetti, A.M. and Colantoni, P. (1973) Stratigrafia dell'Isola di Lampione (Canale di Sicilia). Giorn. Geol. 39 (1): 313-320.

Bosence, D.W.J. and Pedley, H.M. (1982) Sedimentology and palaeoecology of a Miocene coralline algal biostrome from the Maltese Islands. Palaeogeogr. Palaeoclimatol. Palaeoecol. 38: 9-43.

Burollet, P.F.; Mugniot J. and Sweeney, P. (1978) The geology of the Pelagian Block. The margins and basins of southern Tunisia and Tripolitania. In: A.E.M. Nairn, W.H. Kanes and F.G. Stehli (editors) The ocean basins and margins 4B, New York: Plenum Press, pp. 331-359.

Carbone S. and Lentini F. (1981) Caratteri deposizionali delle vulcanti del Miocene superiore negli Iblei (Sicilia sud-orientale). Geol. Rom. 20: 79-104.

Colantoni, P. (1975) Note de geologia marina sul Canale di Sicilia. Giorn. Geol. 40(1): 181-207.

Colantoni, P. and Borsetti, A.M. (1973) Some notes on geology and stratigraphy of the Strait of Sicily. Bull. Geol. Soc. Greece 10: 31-32.

Colombi, B.; Giese, P.: Luongo, G.; Morelli, C.; Riuscetti, M.; Scarascia, S.; Schutte, K.G.; Strowald, J. and De Visintini G. (1973) preliminary report on the seismic refraction profile GarganoPalermo-Pantelleria (1971). Boll. Geof. Teor. Appl. 15 (59): 225-254.

Crisci, G.M.; De Rosa, R. Lanzafame, G.; Mazzuoli, R.; Sheridan, M.F. and Zuffa, G.G. (1981) Monte Guardia deposits: a Late Pleistocene eruptive cycle on Lipari (Italy). Bull. Volc. 44:241-255.

Delteil, J. (1982) La cadre néotectonique de la sédimentation plio-quaternaire en Tunisie centrale et aux iles Kerkennah. Bull. Soc. Geol. France 24 (2): 187-193.

Di Geronimo, I.; Ghisetti, F.; Grasso, M.; Lentini, F.; Scamarda, G. and Vezzani, L. (1980) Dati preliminari sulla neotettonica della Sicilia sud-orientale. Fogli 273 (Caltagirone), 274 (Siracusa), 275 (Scoglitti), 276 (Ragusa) 277 (Noto). In: C. Bosi (editor) Contributi alla realizzione della Carta Neotettonica d'Italia, pubbl. $\mathbf{n}^{0} 356$ del Prog. Finalizzato Geodinamica, pp. 747-773.

Di Paola, G.M. (1973) The island of Linosa (Sicily Channel). Bull. Volc. 37: 149-174.

Esteban, M. (1979) Significance of the Upper Miocene coral reefs of the western Mediterranean. Palaeogeogr. Palaeoclimatol. Palaeoecol. 29: 169-188.

Ghisetti, F. and Vezzani, L. (1980) The structural features of the Iblean Plateau and of the Mount Judica area (southeastern Sicily): a microtectonic contribution to the deformational history of the Calabrian Arc. Boll. Soc. Geol. Ital. 99: 57-102.

Grasso, M.; Lentini, F.; Lombardo, G. and Scamarda, G. (1980) Distribuzione delle facies cretaceomioceniche lungo l'allineamento Augusta - M. Lauro (Sicilia sud-orientale). Boll. Soc. Geol. Ital. 98: 175-188.

Grasso, M. and Lentini, F. (1982) Sedimentary and tectonic evolution of the eastern Hyblean Plateau (southeastern Sicily) during Late Cretaceous to Quaternary time. Palaeogeogr. Palaeoclimatol. Palaeoecol. 39: 261-280.

Grasso, M.; Lentini, F. and Pedley, H.M. (1982) Late Tortonian-lower Messinian (Miocene) palaeogeography of S.E. Sicily: informations from two new formations of the Sortino Group. Sediment. Geol. 32: 279-300.

Grasso, M and Pedley, H.M. (in press) The Pelagian Islands: A new geological interpretation from sedimentological and tectonic studies and its bearing on the evolution of the central Mediterranean Sea (Pelagian Block).

Haas, A. and Emmermann, R. (1983) Vulkanismus des Pantelleria-Riftsystems. Dargestellt an den Inseln Pantelleria und Linosa. Universität Karlsruhe Berichtsband SFB 108: 437-453.

Illies, J.H. (1969) An intercontinental belt of the world rift system. Tectonophysics 8: 5-29. 
Illies, J.H. (1980) Form and formation of graben structures: The Maltese Islands. In: H. Closs; K.V. Gehlen; J.H. Illies; E. Kuntz; J. Neumann and E. Seibold (editors) Mobile Earth, Bonn: Harold Boldt Verlag, pp. 161-184.

Illies, J.H. (1981) Graben formation: the Maltese Islands, a case history. Tectonophysics 73: 151-168.

Kamoun, Y.; Sorel, D.; Viguier, c. and Benn Ayed, N. (1980) Un grand accident summéridién d'âge post-tyrrhénnien en Tunisie orientale. Comp. Rend. Acad. Sci. Paris sèr. D. 290: 647-649.

Messerli, B. (1958) Linosa. Geog. Helvetica 13: 232-240.

Morelli, C.; Gantar, G. and Pisani, M. (1975) Bathymetry, gravity and magnetism in the Strait of Sicily and in the Ionian Sea. Boll. Geof. Teor. Appl. 17 (65): 39-57.

Pedley, H.M. (1979) Miocene bioherms and associated structures in the Upper Coralline limestone of the Maltese Islands: their lithification and palaeonevironment. Sedimentology 26: 577-591.

Pedley, H.M. (1983) The petrology and palaeoenvironment of the Sortino Group (Miocene) of SE Sicily: evidence for periodic emergence. J. Geol. Soc. 140 (3): 335-350.

Pedley, H.M. and Waugh, B. (1976) Easter field meeting to the Maltese Islands. Proc. Geol. Ass. 87: 343-358.

Pedley, H.M.: House, M.R. and Waugh, B. (1976) The geology of Malta and Gozo. Proc. Geol. Ass. 87: 325-341.

Reuther, C.D. (1983) Muster und Mechanismen dextraler Riedelscherung. Oberrhein. Geol. Abh. 32: 5-14.

Reuther, C.D. (1984a) Tectonics of the Maltese Islands. Centro 1 (1): 1-16.

Reuther, C.D. (1984b) Grabenrandtektonik: Die Maghlaq Störungszone auf Malta-Ưberlagerung von Bewegungsvorgängen als Folge regional-tektonischer Spannungsfeldänderungen. Oberrhein. Geol. Abh. 33: 67-82.

Riedel, W. (1929) Zur Mechanik geolgischer Brucherscheinungen. Centralbl. Min. Geol. Pal. 1929 B: $354-368$.

Schminke, H.U.; Fisher, R.V. and Waters, A.C. (1973) Antidune and chute and pool structures in the Base Surge deposits of the Laacher Sea Area, Germany. Sedimentology 20: 553-574.

Segre, A.G. (1960) Geologia. In: E. Zavattari (editor) Biogeografia delle Isole Pelagie. Rend. Acc. Naz. Quaranta 11 (4): 115-162.

Winnock, E. and Bea, F. (1979) Structure de la Mer Pélagienne. In: Gélogie mediterranéenne-La mer Pélagienne. Ann. Univ. Provence 6 (1): 35-40.

Wohletz, K.H. and Sheridan, M.F. (1983) Hydrovolcanic explosions II. Evolution of basaltic tuff rings and tuff cones. Am. J. Sci. 283: 385-413. 
